\title{
Abrikossoff's tumor: report of a rare tumor and its unusual vulvar location
}

\author{
Tumor de Abrikossoff: relato de tumor raro e de localização incomum na vulva
}

Luciana Leite Crivelin ${ }^{1}$; Marilda Aparecida Milanez Morgado de Abreu²

\begin{abstract}
The first report of granulosa cell tumor occurred in 1926, by Abrikossoff, after whom it was named "Abrikossoff's tumor". It is a benign, uncommon neoplasm, most frequently observed in the head, neck and tongue, being found in the vulva only in $6 \%-7 \%$ of the cases. Its histogenesis is uncertain, probably linked to Schwann cells. The treatment is surgical, with good prognosis. Relapses may occur, and there are descriptions of malignant transformation in the literature. The objective of this paper is to describe a case of granular cell tumor located in the vulva.
\end{abstract}

Key words: vulva; vulvar disease; vulvar neoplasms; granular cell tumor.

\section{INTRODUCTION}

The granulosa cell tumor, also known as Abrikossoff's tumor or granular cell schwannoma, is a rare benign neoplasm that occurs preferably in adults (30-50 years), Blacks, and women, in the proportion of $1: 3^{(9)}$. It may arise in several organs, including the skin, but $70 \%$ of them locate in the head and neck, 30\% in the tongue. Most of the time, it occurs as a single tumor, ranging from $0.5 \mathrm{~cm}$ to $3 \mathrm{~cm}$ in diameter, but in $10 \%$ of the cases, lesions may be multiple, predominating in Blacks ${ }^{(3)}$. Its histogenesis remains uncertain, although most authors sustain the theory of neural origin ${ }^{(5)}$. Nowadays it is thought to have originated from neural crest-derived peripheral nerve-related cells. This hypothesis is strengthened by the immunohistochemical expression of S-100 protein, neuron-specific enolase, Leu7 (CD57) and myelin basic protein in granular cells, such as that which occurs in tumors originated from Schwann cells. In addition, the report on immunoreactivity for vimentin, type IV collagen, laminin, epithelial membrane antigen (EMA), CD68, MAC387, alpha-1antitrypsin, alpha 1-antichymotrypsin and $\mathrm{CD} 34$ demonstrates great cellular heterogeneity in the tumor ${ }^{(5,8)}$. This may be explained by the close relationship between granular cells and the different cell types, such as Schwann, perineural and mesenchymal undifferentiated cells. Controversy exists over the tumor growth, but it might initially be a reactive lesion that later on acquired a neoplastic potential ${ }^{(1,8)}$. Histology is characteristic and does not pose diagnostic difficulty ${ }^{(1,5,8)}$. Malignant behavior occurs in $3 \%$ of the cases, including local infiltration and even metastasis, generally found in visceral and deep tumors ${ }^{(2,7)}$. The treatment of choice is surgical excision, with a usually benign outcome; yet if the tumor is incompletely removed, it presents a high rate of local recurrence $(8 \%-15 \%)^{(6,7)}$.

\section{CASE REPORT}

A 29-year-old female patient from São José do Rio Preto-SP presented with a six-month history of a progressively enlarging nodule in the vulvar region. She was referred to surgery with a diagnostic hypothesis of sebaceous cyst.

Physical examination revealed a single painful lesion of approximately $3 \mathrm{~cm}$ in diameter, firm in consistency, more palpable than visible, little mobile, located in the vulva, at the left labium majus (Figure 1). Due to the diagnostic doubt after the clinical examination, an excisional biopsy of the lesion was performed.

First submission on $22 / 04 / 14$; last submission on 14/07/14; accepted for publication on 14/07/14; published on 20/10/14

1. Dermatologist; post-graduating student of the Dermatology Service of Universidade do Oeste Paulista (UNOESTE)

2. Doctorate in Sciences from Escola Paulista de Medicina da Universidade Federal de São Paulo (EPM-UNIFESP); chief of the Dermatology Service of UNOESTE. 


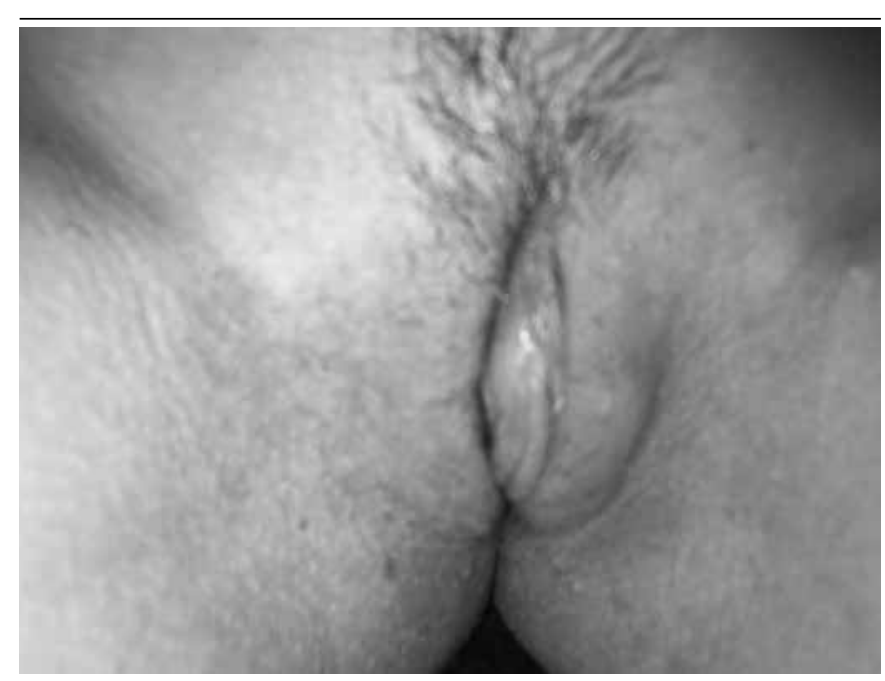

FIGURE 1 -Vulva, left labium majus: presence of a 3-cm-diameter nodule recovered by normal skin

The histopathological analysis evidenced a dermal neoplasm, formed by cells of wide finely eosinophilic granular cytoplasm, containing periodic acid-Schiff (PAS)-positive granules and oval normochromatic nuclei (Figure 2). Immunohistochemistry was suggested and revealed positivity for protein S-100, but negativity for CD57 (Figures 3 and $\mathbf{4}$ ). In view of the results of the histopathologic analysis and the immunohistochemical profile, the diagnosis of granulosa cell tumor was reached. Surgical treatment was chosen, with complete excision and primary closure. The histological analysis of the specimen confirmed the previous diagnosis and demonstrated the total removal of the tumor. The patient was followed-up quarterly in the first year and then biannually. After almost three years of follow-up she does not present tumor recurrence.

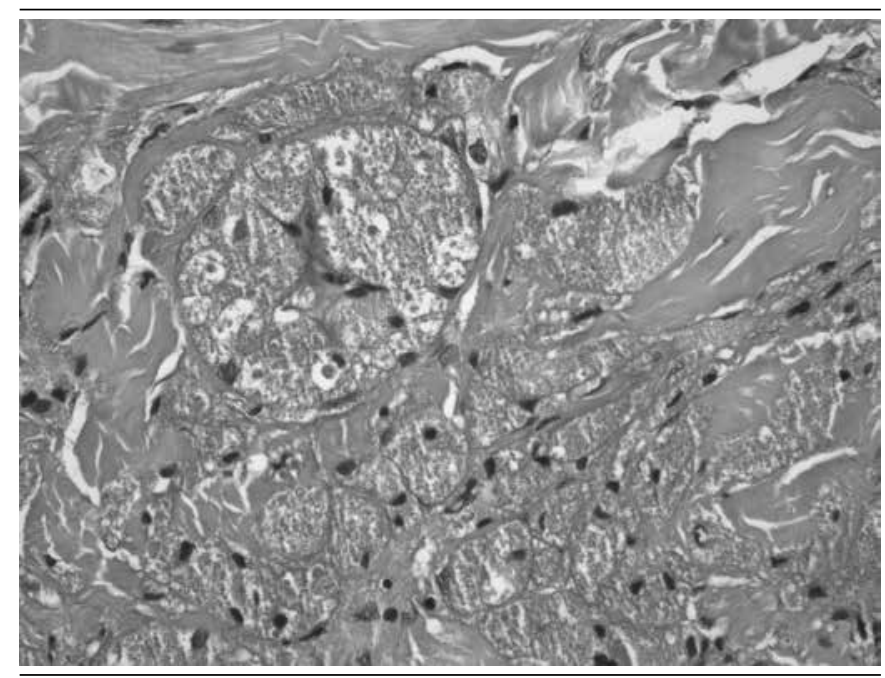

FIGURE 2 - Histopathological exam of vulvar skin: cells with wide finely eosinophilic granular cytoplasm and oval normochromatic nuclei. Magnification 40x

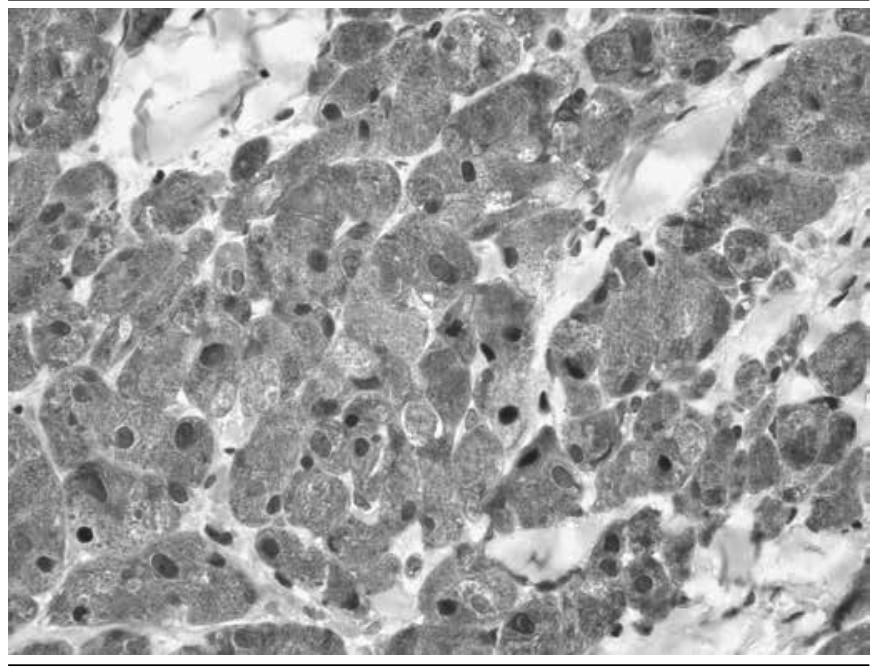

FIGURE 3 - Positivity for protein S-100 (immunohistochemistry). Magnification 40×

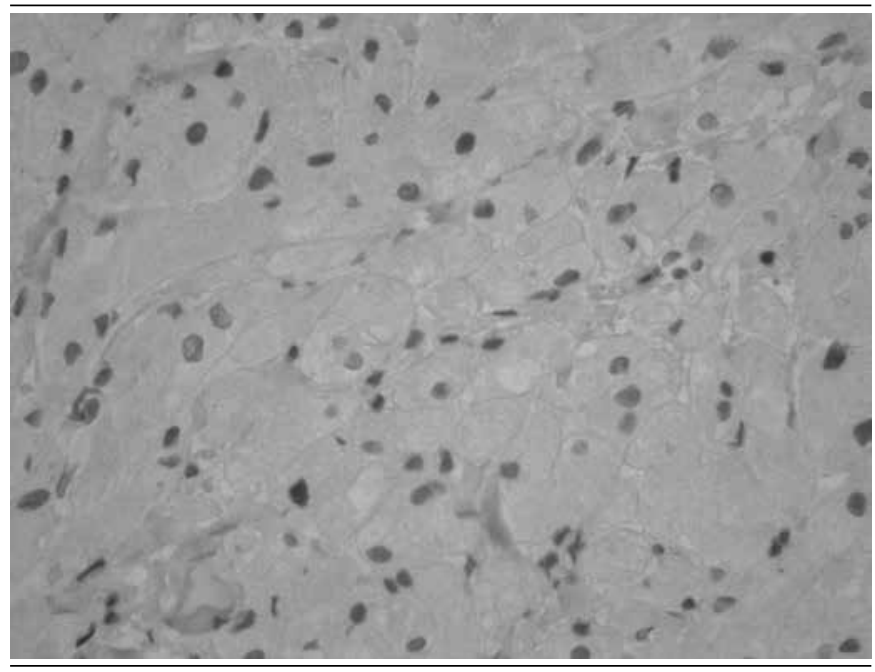

FIGURE 4 - Negativity for marker CD57 (immunobistochemistry). Magnification 40×

\section{DISCUSSION}

Besides the rarity of Abrikossoff's tumor, the vulvar location observed in this case is an uncommon finding, as most cases occur in the head and neck region ${ }^{(6,7)}$. Just $5 \%-7 \%$ of them are described in the vulva. Even though, among the possible diagnoses for vulvar nodules, Abrikossoff's tumor must be thought of.

The tumor presents with a dermal or subcutaneous papule or nodule that is firm, asymptomatic or little painful, and sometimes pruritic and slow-growing. It may be normochromic or reddishbrown ${ }^{(3)}$, occasionally exhibiting ulceration or verrucous surface ${ }^{(3,}$ 9). The lesion is clinically unspecific; diagnosis is based on histopathology, whose findings reveal a poorly circumscribed lesion, 
composed of pale polygonal cells, with abundant eosinophilic cytoplasm, containing PAS-positive and diastase-resistant granules, and round and normochromatic nuclei. The largest intracytoplasmic eosinophilic granules are known as pustuloovoid bodies of Milian. The overlying epidermis may be acanthotic, with increased mitotic rate. The presence of necrosis, high mitotic activity, cellular pleomorphism with evident vesicular nuclei and nucleoli are indicators of aggressive behavior. Because it is not encapsulated, it may infiltrate the adjacent connective tissue ${ }^{(1,5)}$.

The histopathological findings of this case are similar to those previously described, but in spite of the positivity for protein S-100 seen in the immunohistochemical reaction of most benign tumors in the peripheral nerve shear, negativity for $\mathrm{CD} 57$ was observed. This does not exclude the diagnosis of Abrikossoff's tumor, for in this neoplasm, the amount of cells showing reactivity for $\mathrm{CD} 57$ is variable: reports range from completely negative lesions to those with more than $50 \%$ of the neoplastic cells being marked ${ }^{(4)}$.

The differential diagnosis of skin lesions must be done with dermatofibroma, skin-appendage tumors, compound melanocytic nevi and seborrheic keratosis ${ }^{(2,7)}$. In the tongue, it may be confused with spinocellular carcinoma in very superficial biopsies for inducing pseudoepitheliomatous hyperplasia of the epithelium. In the vulvar region, differential diagnosis includes Bartholin's cyst, lipoma, papilloma, hidradenoma and fibroma ${ }^{(7)}$.

This neoplasia is treated by complete excision. The prognosis is good, but local relapse may occur if surgical margins are inadequate ${ }^{(6)}$.

\section{RESUMO}

O primeiro relato do tumor de células granulosas ocorreu em 1926, por Abrikossoff, nome que deu origem à denominação "tumor de Abrikossoff". Trata-se de neoplasia benigna, incomum, observada mais frequentemente na cabeça, no pescoço e na lingua, sendo encontrado na vulva em apenas 6\%-7\% dos casos. Sua histogênese é incerta, provavelmente ligada às células de Schwann. O tratamento é cirúrgico, com bom prognóstico. Podem ocorrer recidivas, e existem descrições de malignização na literatura. O objetivo deste trabalbo é descrever um caso de tumor de células granulares localizado na vulva.

Unitermos: vulva; doenças da vulva; neoplasias vulvares; tumor de células granulares.

\section{REFERENCES}

1. ABRIKOSSOFF, A. L. Über Myome, ausgehend von der quergestreiften willkürlichen Muskulatur. Virchows Arch A Pathol Anat Histopathol, v. 260, n. 1, p. 215-33, 1926.

2. APISARNTHANARAX, P. Granular cell tumor: an analysis of 16 cases and review of literature.J Am Acad Dermatol, v. 5, n. 2, p. 171-82, 1981.

3. BOLOGNA,J. L.; JORIZZO,J. L.; RAPINI, R. P. Neural and neuroendocrine neoplasms. In: BOLOGNA, J. L.; JORIZZO, J. L.; RAPINI, R. P. Dermatology.

2. ed. Philadelphia: Mosby, 2003. Cap. 23; p. 1843-59.

4. CHRYSOMALI, E. et al. Benign neural tumors of the oral cavity: a comparative immunohistochemical study. Oral Surg Oral Med Oral Pathol Oral Radiol Endod, v. 84, n. 4, p. 381-90, 1997.
5. JUNQUERA, L.; de VICENTE, J.; LOSA, J. L. Granular-cell tumor: an immunohistochemical study. Br J Oral Maxillofac Surg, v. 35, n. 3, p. 180-4, 1997

6. LEVAVI, H. et al. Granular cell tumor of the vulva: six new cases. Arch Gynecol Obstet, v. 273, n. 4, p. 246-9, 2006.

7. LIEB, S. M.; GALLOUSIS, S.; FREEDMAN, H. Granular cell myoblastoma of the vulva. Gynecol Oncol, v. 8, n. 1, p. 12-20, 1979.

8. MAIORANO, E. et al. Cellular heterogeneity of granular cell tumours: a clue to their nature? J Oral Pathol Med, v. 29, n. 6, p. 284-90, 2000.

9. ORTIZ-HIDALGO, C.; de LA VEGA, G. Granular cell tumor (Abrikossoff tumor) of the clitoris. Int J Dermatol, v. 36, n. 12, p. 935-7, 1997. 